\title{
Wood Anatomical Structures of Tropical Acacias and its Implication to Tree Breeding
}

\author{
Arif Nirsatmanto $^{1^{*}}$, Sri Sunarti ${ }^{1}$, Harry Praptoyo ${ }^{2}$ \\ ${ }^{I}$ Center for Forest Biotechnology and Tree Improvement, Yogyakarta, Indonesia \\ ${ }^{2}$ Faculty of Forestry, Gadjah Mada University, Yogyakarta, Indonesia
}

*Corresponding Author: Arif Nirsatmanto, Center for Forest Biotechnology and Tree Improvement, Yogyakarta, Indonesia, Email ID: arifnirsatmanto@biotifor.or.id

\begin{abstract}
Some Acacia species are well domesticated in some regions for supplying raw material for industries. Achievement in wood technology and tree breeding had made the product diversification from the Acacias are becoming more attractive. As a fundamental component, however, the information in wood anatomical structure of the Acacias was still limited. This study is aimed to observe wood anatomical structures of four tropical Acacias obtained from a tree improvement program. The wood samples were collected from three years age of four Acacias: Acacia mangium, Acacia auriculiformis, and their hybrids (A. mangium $x$ A. auriculiformis and A. auriculiformis $x$ A. mangium) planted in Acacia hybrid seed orchard. The wood anatomical structures were observed including some macroscopic and microscopic features. The results showed that wood anatomical structures varied among the four Acacias. Some macroscopic features were similar, while the microscopic were slightly variable. Significant difference $(p<0.05)$ was found in proportion of rays and fiber. All fiber dimensions were significant ( $p<0.05)$, except for fiber length. Acacia hybrid showed a specific microscopic feature compared to their pure parent species. The results suggest that the change in genetic behavior through breeding process seemed potentially affected the change in wood anatomical structure of the four Acacias.
\end{abstract}

Keywords: Wood properties, macroscopic features, microscopic features, tree breeding, Acacia hybrid.

\section{INTRODUCTION}

Some species in the genus of Acacia were introduced in tropical regions mostly for supplying raw material for forest industries, such as pulp and paper, sawn timber and wood energy. Indonesia, Malaysia, Vietnam, China, India, Philipines, and Thailand were reported as the countries concern for Acacia plantations in the tropic areas [1]. The establishment of Acacias plantations were practiced either by large scale plantation companies or by smallholder grower.

The two largest species of Acacias for plantation in Indonesia are Acacia mangium and Acacia auriculiformis. Although these two Acacias were found growing naturally in Eastern part of Indonesia [2], the Acacia plantation was firstly introduced in 1975's as a part of national land rehabilitation program [3]. Recently market-oriented has driven the Acacias plantation to be economically feasible for diverse end-product. Current new achievement in wood processing technology have made the Acacias could be potentially improved for varies end-product purposes $[4,5,6,7,8,9]$. In addition, progress of breeding in tree improvement program succeeded to improve the stand productivity of the Acacias and produced new variety of Acacia hybrid, an out crossing between A. mangium and A. auriculiformis $[10,11,12,13,14,15]$. Based on these two achievement technologies, recently the chance for the end-product diversification from the Acacias wood becomes more attractive.

The knowledge of wood anatomical structure is a fundamental component to support the utilization of wood from a forest tree species. Based on this anatomical structure the uses of wood for suitable endproduct could be explored. However, the anatomical structure of wood may potentially change during the process of breeding either due to the process of selection or gene recombination through a mating $[16,17,18]$. Therefore, this study was conducted to observe the wood anatomical structure of four improved Acacias: A. mangium, A. auriculiformis and the two Acacia hybrids which were resulted from tree improvement program in Indonesia. 


\section{Materials AND Methods}

\subsection{Hybrid Seed Orchard}

All wood sample used in this study were collected from the trees planted in hybrid seed orchard (HSO). This HSO was established for producing Acacia hybrid seed as the result of the inter-specific out crossing between A. mangium and A. auriculiformis. To optimize the crossing rate, two mother tree species of A. mangium and A. auriculiformis, with a total around 12,000 trees, were planted in the same area using an alternating rows design with an initial spacing of $3 \mathrm{~m} \times 1 \mathrm{~m}: 3$ meter between rows species and 1 meter within row species [25]. The seed of two mother tree species planted in the HSO were collected from selected plus trees in respective first-generation seedling seed orchard. Thinning was practiced twice in the HSO for retaining final stand density around 3000 selected tress which is subjected as seed trees for producing Acacia hybrid seed.

\subsection{Sample Tree Selection}

Tree selection for wood sample collection in HSO was practiced at three years age in four species: 1) A. mangium, 2) A. auriculiformis, 3) A. mangium x A. auriculiformis (hereinafter referred as "AM $\mathrm{x}$ AA") hybrid, 4) A. auriculiformis x A. mangium (hereinafter referred as "AA x AM") hybrid. The $A$. mangium and AM x AA hybrid sample tree were selected in the A. mangium's rows, while for the $A$. auriculiformis and AA x AM hybrid were selected in A. auriculiformis's rows. To detect the hybrid status, all of the Acacia hybrid trees selected based on their morphological markers were then verified using molecular marker before collecting wood sample [25]. Three sample trees for each of four Acacias species were selected for wood sample collection. The ranges of growth for all selected sample trees were around $18-19.7$ meter for height and $16-17.3 \mathrm{~cm}$ for diameter at breast height (dbh).

\subsection{Wood Sample Collection}

Each selected sample tree was cut at $1.3 \mathrm{~m}$ above the ground and then the stem disk with $5 \mathrm{~cm}$ thickness was collected at three different parts of stem height from dbh to the top of bole length (Figure 1). Cross section with $2 \mathrm{~cm} \mathrm{x} 6 \mathrm{~cm} \times 10 \mathrm{~cm}$ was obtained from central stem disk. Afterward, for fiber dimension observation, section with $1 \mathrm{~mm} \times 1 \mathrm{~mm} \times 20 \mathrm{~mm}$ was prepared which was then put into a bottle containing a combination glacial acetic acid and hydrogen peroxide (perhidrol) in 1:20 (v/v) for further maceration using Franklin's method. For proportion of cell observation, thin transversals section in radial and tangential about $10-20 \mu \mathrm{m}$ thick were cut by using microtome for preparing permanent slides which were then observed using microscope fluorescence photograph type 51 supported by the Image Pro Plus V. 4.5.

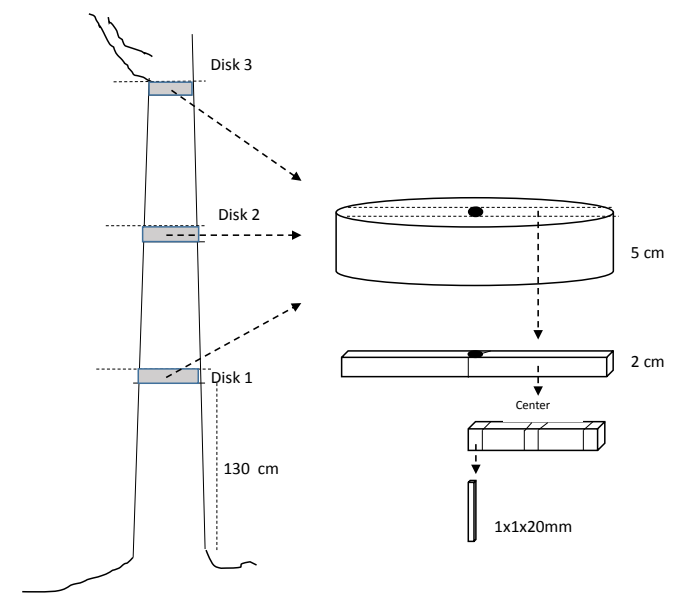

Figure 1. The wood sample collection method for four Acacias species [25]

\subsection{Assessment and Data Analysis}

Assessments were conducted through observing the macroscopic and microscopic characters. The macroscopic were observed including wood structure characters using loupe with the magnifying of power 12 - 15 times. For the microscopic, the observation included the proportion cells: rays, fiber and vessels, and wood fiber dimensions: fiber length, fiber diameter, lumen diameter, and fiber wall thickness. 
Analysis of variance (ANOVA) was performed in all collected data to provide a statistical comparison between the species using the following linear model:

$y_{i j}=\mu+x_{i}+\varepsilon_{i j}$

where:

$y_{i j}=$ observations, $\mu=$ mean $x_{i}=$ the $i$ species effect, $\varepsilon_{i j}=$ error associated with $y_{i j}$.

All data presented in percentage (\%) were transformed into Arc Sine $\sqrt{\mathrm{x}}$ before the analyses [19].

\section{RESULTS AND DISCUSSION}

\subsection{General Features}

In general, the four observed Acacias showed some similarities in macroscopic features. The woods were diffuse porosity with growth ring boundaries indistinct. The average number of vessel was 5-9 $\mathrm{mm}^{-2}$ in solitary and multiple radial (Figure 2). The average tangential diameter of vessel was ranging from $0.115-0.145 \mathrm{~mm}$. The A. auriculiformis and AM x AA hybrid showed more multiple radial vessels than the A. mangium and AA x AM hybrid.
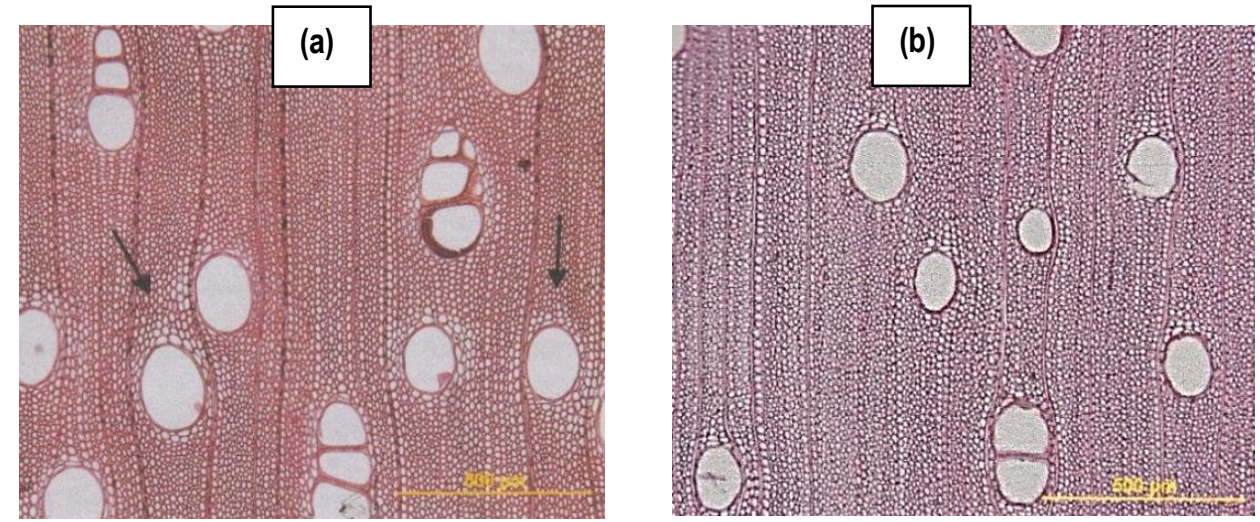

Figure 2. Transverse section showing vessel for (a) A. auriculiformis and A. mangium $x A$. auriculiformis hybrid and (b) A. mangium and A.auriculiformis $x$ A. mangium hybrid
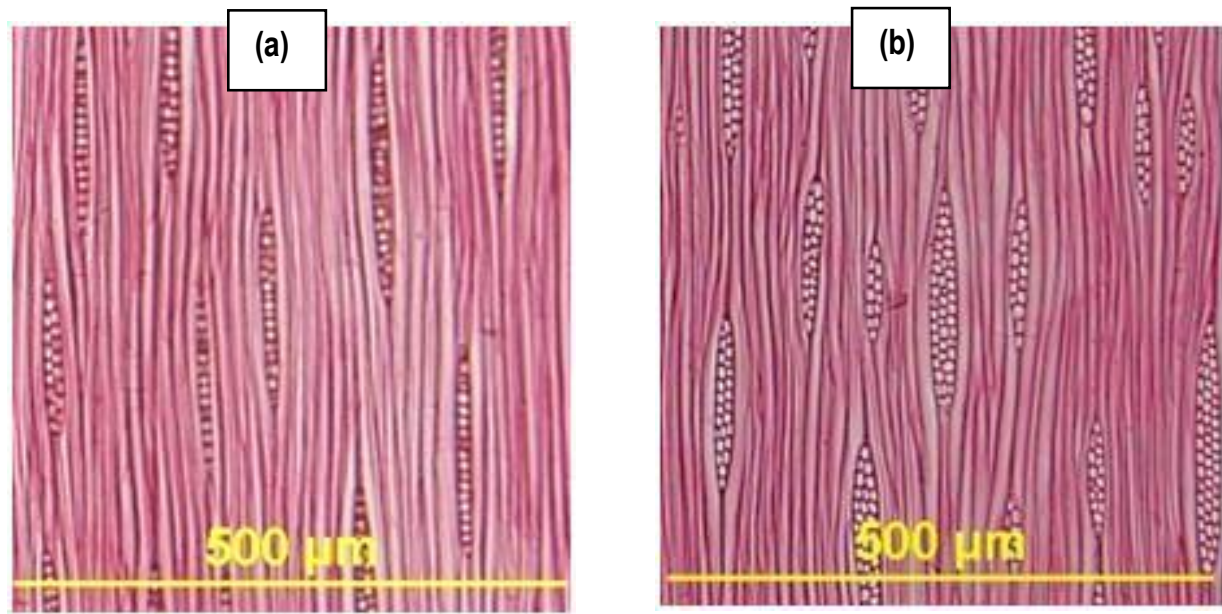

Figure 3. Tangential section showing (a) uniseriate / biseriate rays observed in all of the four Acacia species and (b) multiseriate rays observed only in A. auriculiformis and A. auriculiformis $x$ A. mangium hybrid

The four Acacias were mostly dominated with uniseriate and biseriate rays, but multiseriate ray was also found in the two Acacias: AA x AM hybrid and A. auriculiformis (Figure 3). The average length of ray was ranging from $0.167-0.205 \mathrm{~mm}$. The axial parenchyma was paratracheal vasicentric for all of four Acacias.

It should note here that the wood sample used in this study were collected at younger age (3 years age) than the usually harvesting age practiced in Acacias plantation $(6-10$ years age). Therefore 
some characteristics may change in older age, such as for tangential diameter of vessels and length of ray. Another considered factor is the climates of site in where the wood sample was collected. The climate type of the site trial is $\mathrm{C}$ according to Schmidt and Ferguson with high average temperature at $26.5^{\circ} \mathrm{C}$, and low annual rainfall at $1.878 \mathrm{~mm} /$ year [15]. Some studies reported that the differences in growth, age and site climates affected the wood anatomical structure of a tree species [20, 21, 22, 23]. In addition, the four Acacias used in present study are the same genus. In this case, there will be some possibilities to gene transfer among the four Acacias through mating that affected the growth and the wood anatomical structures. This will be discussed later following the description of breeding and genetic impacts.

\subsection{Proportion of Cell}

The observed proportion cell of the four Acacias is presented at Table 1. Except for the proportion of vessels, the proportion of cells was significantly different $(\mathrm{P}<0.05)$ among the four Acacias. According to these results, the greatest variation of the proportion of cells was observed in proportion of fiber. Although the wood sample in the present study were collected in younger age, the proportion of fiber ( $>68 \%$ ) was higher as compared to the other study using three out of four Acacias species at mature age [24]. On the other hand, other parameters were lower.

Table 1. Proportion of cells in the wood of four Acacia species at three years age

\begin{tabular}{|l|l|l|l|}
\hline \multirow{2}{*}{ Species } & \multicolumn{4}{l|}{ Proportion of cells (\%) } & Fiber \\
\cline { 2 - 4 } & Vessel & Ray & $74.29 \pm 2.39 \mathrm{ab}$ \\
\hline A. mangium & $9.29 \pm 0.88 \mathrm{a}$ & $8.23 \pm 1.03 \mathrm{a}$ & $73.08 \pm 1.73 \mathrm{~b}$ \\
\hline A. auriculiformis & $8.64 \pm 0.80 \mathrm{a}$ & $8.84 \pm 1.03 \mathrm{a}$ & $68.90 \pm 6.96 \mathrm{c}$ \\
\hline AM x AA hybrid & $9.13 \pm 1.35 \mathrm{a}$ & $7.66 \pm 1.22 \mathrm{~b}$ & $75.89 \pm 2.66 \mathrm{a}$ \\
\hline AA x AM hybrid & $8.76 \pm 0.50 \mathrm{a}$ & $8.57 \pm 1.80 \mathrm{a}$ & \\
\hline
\end{tabular}

Remark: average numbers followed by the same letters in a column were not significantly different at the level of $5 \%$

In general, the superiority in proportion of cells varied among the four Acacias. A. mangium showed the highest value in proportion of vessel. A. auriculiformis showed the highest value in proportion of rays, but the lowest in proportion of vessel. The opposite condition was observed between the two Acacia hybrids. The AM x AA hybrid showed higher value in the proportion of vessel, but it was lower in proportion of ray. On the contrary, the AA x AM hybrid showed higher value in proportion of ray, but it was lower in proportion of vessel. In case proportion of fiber, the AA x AM hybrid showed the highest value, while for AM x AA hybrid was the lowest. It indicates that the higher performance of each Acacia hybrid in the proportion of cells was likely affected by the superiority of their female parent species in respective characteristic.

\subsection{Fiber Dimensions}

The fiber dimensions of the wood from the four Acacias as used in this study were previously reported and the value is presented at Table 2 [25]. Except for the fiber length, all fiber dimensions were significantly different $(p<0.05)$ among the four Acacias. In general, the fiber dimensions observed in present study were lower as compared to the other study at mature age [24]. Although a direct comparison between these two studies is not appropriate because of the differences in the sites and stand, it revealed that the age likely affected the change of fiber dimension of Acacia species.

Table 2. Fiber dimension of the wood of four Acacias species at three years age

\begin{tabular}{|l|l|l|l|l|}
\hline Species & $\begin{array}{l}\text { Fiber length } \\
(\mathrm{mm})\end{array}$ & Fiber diameter $(\mu \mathrm{m})$ & $\begin{array}{l}\text { Fiber lumen diameter } \\
(\mu \mathrm{m})\end{array}$ & $\begin{array}{l}\text { Fiber wall thickness } \\
(\mu \mathrm{m})\end{array}$ \\
\hline A. mangium & $0.86 \pm 0.01 \mathrm{a}$ & $17.07 \pm 1.10 \mathrm{a}$ & $13.30 \pm 1.06 \mathrm{a}$ & $1.89 \pm 0.05 \mathrm{a}$ \\
\hline A. auriculiformis & $0.84 \pm 0.04 \mathrm{a}$ & $14.47 \pm 0.68 \mathrm{~b}$ & $11.32 \pm 0.37 \mathrm{~b}$ & $2.15 \pm 0.32 \mathrm{a}$ \\
\hline AM x AA hybrid & $0.78 \pm 0.03 \mathrm{a}$ & $13.86 \pm 0.77 \mathrm{~b}$ & $11.42 \pm 0.39 \mathrm{~b}$ & $1.22 \pm 0.19 \mathrm{~b}$ \\
\hline AA x AM hybrid & $0.85 \pm 0.09 \mathrm{a}$ & $16.09 \pm 0.18 \mathrm{a}$ & $12.56 \pm 0.17 \mathrm{a}$ & $1.77 \pm 0.01 \mathrm{a}$ \\
\hline
\end{tabular}

Source: modified from [25]

Remark: average numbers followed by the sane letters in a column were not significantly different at the level of $5 \%$ 
Based on the fiber dimension properties as mentioned above, the four Acacias are classified as the short fiber tropical species (fiber length $\leq 0.900 \mathrm{~mm}$ ). The value of fiber dimension is important to assess the suitability of the wood for the type of end-product, especially for pulp and paper. This is because the derived values of fiber dimension will be used to determine the strength and quality of the paper product. Based on the level of fiber quality for pulp, the four Acacias species used in present study were classified as level II.

\subsection{Genetic Effects}

Genetically, the relationship among the four Acacias used in present study are the pure parents species and their hybrid's progeny species. The A. mangium and A. auriculiformis was used as parents to obtain the AM x AA hybrid and the AA x AM hybrid progeny. Therefore, the characteristics from the two parents were potentially transmitted into the hybrid progeny, including the characteristic of wood anatomical structures. Based on the genetic background of the four Acacias species, the results revealed that genetic factor affected the wood anatomical structure of the four Acacias. In another study, it was reported that the effect of genetic on anatomical characteristics was also observed in $A$. mangium from five different provenances [26].

Some specific wood anatomical characteristics were observed in the Acacia hybrid. The strength of gene transmits between A. mangium and A. auriculiformis parent to their hybrid's progeny was different in relation to the wood anatomical structures. The number of vessel in the hybrid progeny was dominated by the male genes rather than female genes, either in AM x AA hybrid or AA x AM hybrid. On the other hand, the serial of rays was dominated by the female genes, rather than the male genes. It means that in the breeding process through a mating among the Acacias species, a better male parent will provide better wood vessel, while a better female parent will provide better of ray characteristics.

Similar with the results in preceding paragraph, varies dominancy among the parent genes was also observed in the relation of proportion of cells and fiber dimensions. Female genes, either A. mangium or A. auriculiformis, will dominate an effect in proportion of vessel and rays, while the male genes seemed dominate the proportion of fiber (Table 1). These were clearly observed in the AM $\mathrm{x}$ AA hybrid for proportion of vessel and the AA x AM hybrid for proportion of ray. Both hybrid progenies showed better characteristics due to a better parent female gene in the respective characteristic. Whereas in the proportion of fiber, the best characteristic was found in the AA x AM hybrid and it suggests that this hybrid progeny showed better characteristic due to better parent male gene. Moreover, the highest value for proportion of fiber in the AA x AM hybrid might be also due to the effect of heterosis that occurred in the Acacia hybrid progeny.

In case fiber dimension, all characteristics were likely dominated by the male genes, except for fiber wall thickness. This is clearly shown by the dominance of A. mangium as male genes for fiber dimensions in the AA x AM hybrid. These both species were two of the top species showing higher value of fiber length, fiber diameter and fiber lumen diameter (Table 2). It means that the gene in $A$. mangium that controlled the fiber dimensions was well expressed into their progeny of AA $\mathrm{x}$ AM hybrid with the $A$. mangium as male parent.

The point of discussion in preceding paragraph suggests that maternal and paternal parents had considerable effect in wood anatomical structure of Acacia species, particularly in the Acacia hybrid. However, it should be noted in here that the four Acacias used in present study were planted using seed from open pollination with no specific mating design applied. Therefore further research using a controlled mating design is needed to get more complete and detail genetic understanding on the phenomenon of maternal and paternal effect for Acacia species. Some other studies also revealed that maternal and paternal parent clearly affected some characteristics of plant, such as Eucalyptus globulus [27], mulberry [28], Purshia tridentata [29].

\subsection{Implication to Breeding in Acacia Hybrid}

The genetic effects as described in the preceding section indicate some implications on how to utilize the variation in anatomical structures in Acacia breeding program. The different effect on the dominance of female and male parent genes in wood anatomical structure implies that the mating process among the four Acacia species should be clearly directed in an appropriate combination. In 
another case, selection criteria in breeding population of each pure parent (A. mangium and A.auriculiformis) should be well defined in relation to the wood anatomical characteristics.

Although some characteristics showing a little variation, in general the two pure parents species provided a difference in their superiority. The A. mangium showed higher value in vessels and fiber characteristic, while A. auriculiformis showed higher value in ray (Table 1 and Table 2). All fiber dimensions showed that $A$. mangium was superior to A. auriculiformis, except for fiber wall thickness. The superiority was clearly observed in the significant differences of fiber diameter and fiber lumen diameter (Table 2). The superiority on fiber characteristics of A. mangium could be potentially transmitted into their progeny if the A. mangium is mated as male parent species with $A$. auriculiformis as female parent. Therefore to support the hybrid breeding program, selecting better fiber characteristics in A. mangium then followed by a mating with female of A. auriculiformis will potentially produce AA x AM hybrid progeny which having more improved fiber characteristics than that in AM x AA hybrid.

Among the Acacia hybrid used in present study, the wood of AA x AM hybrid showed better fiber dimension than the wood of AM x AA hybrid (Table 2). Fiber dimension is important wood anatomical characteristic for pulp product. In addition, the Acacia hybrid was reported having a better growth and disease tolerance than their pure parents [15, 24, 30, 31, 32]. Therefore, improving stand productivity through breeding program of Acacias could be potentially obtained by developing the new variety of AA x AM hybrid which was completed with better fiber characteristics.

\section{CONCLUSION}

The results of present study revealed that the wood anatomical structure varied among the four observed Acacia species. Considering the superiority, both A. mangium and A. auriculiformis affected the wood anatomical characteristic in different manner. The inter specific hybridization between the both Acacia parents species would potentially produce Acacia hybrid with better wood anatomical structures, mostly in relation to the fiber, vessels and ray characteristics. However, appropriate mating combination through selecting the parent as female or male in producing the Acacia hybrid should be taken into account during the process of breeding by considering the superiority each pure parent in anatomical characteristic. For instance, fiber characteristics as one of important elements in producing wood for pulp and paper could be improved through the Acacia hybrid with A. mangium as male parent and A. auriculiformis as female parent. Therefore, the results of present study imply that to support the Acacia hybrid breeding program, improving the pure parent species with concerning the respective superiority in wood anatomical characteristic should be practiced first.

\section{ACKNOWLEDGEMENT}

We wish to thank Research Team members of tree improvement for pulp in CFBTI, Yogyakarta for wood sample collection. Many thanks to Gadang Priya Sahaja, Candra Dwi Laksana, Mahadi Dwi Nurwasis and Endy Hasan Sholeh for laboratory working.

\section{REFERENCES}

[1] Turnbull, J. W., Midgley, S. J., \& Cossalter, C. (1998). Tropical Acacias planted in Asia: an overview. In J. W. Turnbull, H. R. Crompton, \& K. Pinyopusarerk (Eds.), Recent Development in Acacia Planting: Proceedings of an international workshop held in Hanoi, Vietnam, 27-30 October, 1997 (p. 383). Canberra: ACIAR Proceedings No. 82.

[2] Gunn, B. V., \& Midgley, S. J. (1991). Exploring and accessing the genetic resources of four selected tropical Acacias. In J. W. Turnbull (Ed.), Advances in Tropical Acacia Research: Proceedings of an international workshop held in Bangkok, Thailand, 11-15 February 1991 (p. 234). Canberra: ACIAR Proceedings No. 35.

[3] Arisman, H., \& Hardiyanto, E. B. (2006). Acacia mangium - a historical perspective on its cultivation. In P. Karina, A. Rimbawanto, \& C. Beadle (Eds.), Heart Root and Root Rot in Tropical Acacia Plantations: Proceedings of a workshop held in Yogyakarta, Indonesia, 7-9 February 2006. (p. 92). Canberra: ACIAR Proceedings No. 124. Retrieved from http://scholar.google.com /scholar?hl=en\&btnG= Search\&q =intitle: Heart+ rot+and+root+rot+in+tropical+Acacia+plantations\#0.

[4] Chowdhury, M. Q., Shams, M. I., \& Alam, M. (2005). Effects of age and height variation on physical properties of mangium ( Acacia mangium Willd.) wood. Australian Forestry, 68(1), 17-19.

[5] Jahan, M. S., Sabina, R., \& Rubaiyat, A. (2008). Alkaline pulping and bleaching of Acacia auriculiformis 
grown in Bangladesh. Turkish Journal Agriculture and Forestry, 32, 339-347. Retrieved from http://journals.tubitak.gov.tr/agriculture/issues/tar-08-32-4/tar-32-4-12-0708-10.pdf.

[6] Ratnasingam, J., Abdullah, A. Z., Ramasamy, G., \& Seng, C. Y. (2013). A review of different sawing and drying techniques used in processing small-diameter logs. Journal of Applied Sciences, 13(3), 341-347.

[7] Rosli, W. D., Mazlan, I., \& Law, K. N. (2009). Effects of kraft pulping variables on pulp and paper properties of Acacia mangium kraft pulp. Cellulose Chemistry Technology, 43(1-3), 9-15. Retrieved from www.cellulosechemtechnol.ro/pdf/CCT1-3-2009/p.9-15.pdf.

[8] Tabet, T. A., \& Fauziah, H. A. A. (2010). Estimation of the cellulose microfibril angle in Acacia mangium wood using small-angle X-ray scattering. Journal of Agricultural Science, 2(4), 139-148. Retrieved from www.ccsenet.org/journal/index.php/jas/article/download/8407/6226.

[9] Tenorio, C., Moya, R., \& Quesada-Pineda, H. J. (2012). Kiln drying of Acacia mangium wood: colour, shrinkage, warp, split and check in dried lumber. Journal of Tropical Forest Science, 24(1), 15-139. Retrieved from https://www.frim.gov.my/v1/jtfsonline/jtfs/v24n1/125-139.pdf.

[10] Harwood, C. E., Hardiyanto, E. B., \& Wong, C. Y. (2015). Genetic improvement of tropical Acacias: achievements and challenges. Southern Forests: A Journal of Forest Science, 77(7), 11-18. https://doi.org/10.2989/20702620.2014.999302.

[11] Huong, V. D., Nambiar, R. K. S., Quang, L. T., Mendham, D. S., \& Dung, P. T. (2015). Improving productivity and sustainability of successive rotations of Acacia auriculiformis plantations in South VietnamNo Title. Southern Forests: A Journal of Forest Science, 77(1), 51-58. https://doi.org/10.2989/20702620.2014.983360.

[12] Nambiar, E. K. S., Harwood, C. E., \& Kien, N. D. (2015). Acacia plantations in Vietnam: research and knowledge application to secure a sustainable futureNo Title. Southern Forests: A Journal of Forest Science, 77(1), 1-10. https://doi.org/10.2989/20702620.2014.999301.

[13] Nirsatmanto, A., Setyaji, T., Sunarti, S., \& Kartikaningtyas, D. (2015). Genetic gain and projected increase in stand volume from two cycles breeding program of Acacia mangium. Indonesian Journal of Forestry Research, 2(2), 71-79. https://doi.org/http://dx.doi.org/10.20886/ijfr.2015.2.2.71-79.

[14] Sedgley, M., Harbard, J., Smith, R. M., Wickneswari, R., \& Griffin, A. R. (1992). Reproductive Biology and Interspecific Hybridisation of Acacia mangium and Acacia auriculiformis A. Cunn. ex Benth. (Leguminosae: Mimosoideae). Australian Journal of Botany, 40, 37-48.

[15] Sunarti, S., Na'iem, M., Hardiyanto, E. B., \& Indrioko, S. (2013). Breeding strategy of Acacia hybrid (Acacia mangium $\times$ A. auriculiformis) to increase forest plantation productivity in Indonesia. Jurnal Manajemen Hutan Tropika (Journal of Tropical Forest Management), XIX(2), 128-137. https://doi.org/10.7226/jtfm.19.2.128.

[16] Lenz, P., MacKay, J., Rainville, A., Cloutier, A., \& Beaulieu, J. (2011). The influence of cambial age on breeding for wood properties in Picea glauca. Tree Genetics \& Genome, 7(3), 641-653. https://doi.org/10.1007/s11295-011-0364-8.

[17] Nyakuengama, J. G., Matheson, C., Spencer, D. J., Evans, R., \& Vindem, P. (1997). Time trends in the genetic control of wood microstructure traits in Pinus radiata. Appita Journal, 50, 486-494.

[18] Zobel, B. J., \& van Buijtenen, J. P. (1989). Wood variation its causes and control. (T. E. Timell, Ed.). Berlin Heidelberg: Springer-Verlag.

[19] Gomez, K. A., \& Gomez, A. A. (1984). Statistical procedures for agricultural research. Canada: John Wiley \& Sons, Inc.

[20] Honjo, K., Furukawa, I., \& Sahri, M. H. (2005). Radial Variation of Fiber Length Increment in Acacia mangium. IAWA Journal, 26(3), 339-352.

[21] Ismail, J., Jusoh, M. Z., \& Sahri, M. H. (1995). Anatomical variation in planted kelempayan (Neolamarckia cadamba, Rubiaceae). IAWA Journal, 16(3), 227-287.

[22] Moya, R., \& Fo, M. T. (2008). Variation in the wood anatomical structure of Gmelina arborea (Verbenaceae) trees at different ecological conditions in Costa Rica. Rev Biology Tropical, 56(2), 689704. Retrieved from http://producao.usp.br/handle/BDPI/14747.

[23] Sahri, M. H., Faridah, H. I., \& Aini, A. S. N. (1993). Anatomy of Acacia mangium Grown in Malaysia. IAWA Journal, 14(3), 245-251.

[24] Yahya, R., Sugiyama, J., Silsia, D., \& Gril, J. (2010). Some anatomical features of an Acacia hybrid, A. mangium and $A$. auriculiformis grown in Indonesia with regard to pulp yield and paper strength. Journal of Tropical Forest Science, 22(3), 343-351.

[25] Sunarti, S., Praptoyo, H., \& Nirsatmanto, A. (2016). Karakteristik serat kayu hibrid Acacia auriculiformis $\mathrm{x}$ Acacia mangium sebagai bahan baku pulp (in Indonesian). Jurnal Pemuliaan Tanaman Hutan, 10(2), 135-143. 
[26] Nugroho, W. D., Marsoem, S. N., Yasue, K., Fujiwara, T., Nakajima, T., Hayakawa, M., ... Funada, R. (2012). Radial variations in the anatomical characteristics and density of the wood of Acacia mangium of five different provenances in Indonesia. Journal of Wood Science, 58(3), 185-194. https://doi.org/10.1007/s10086-011-1236-4.

[27] Rix, K., Gracie, A., Potts, B., Brown, P., Spurr, C., Rix, K., ... Spurr, C. (2012). Paternal and maternal effects on the response of seed germination to high temperatures in Eucalyptus globulus. Annal of Forest Science, 69, 673-679. https://doi.org/10.1007/s13595-012-0190-7.

[28] Orus, M., Oraceae, M., \& Urgess, K. E. S. B. (2004). Maternal and paternal contributions to the fitness of hybrids between red and white mulberry (Morus, Moraceae). American Journal of Botany, 91(11), 18021808.

[29] Pendleton, R. L., Mcarthur, E. D., \& Sanderson, S. C. (2012). Breeding system and interaccessional hybridization of Purshia tridentata plants grown in a common garden. Western North American Naturalist, 72(2), 241-249.

[30] Kato, K., Yamaguchi, S., Chigira, S., Ogawa, Y., \& Isoda, K. (2012). Tube pollination using stored pollen for creating Acacia auriculiformis hybrid. Journal of Tropical Forest Science, 24(2), 469-483.

[31] Kha, L. D. (2001). Studies on the use of natural hybrids between Acacia mangium and Acacia auriculiformis in Vietnam. Hanoi: Agriculture Publishing House.

[32] Rokeya, U. K., Hossain, M. A., Ali, M. R., \& Paul, S. P. (2010). Physical and mechanical properties of Hybrid Acacia (Acacia auriculiformis x A. mangium). Journal of Bangladesh Academy of Science, 32(2), 181-187.

Citation: A. Nirsatmanto et al., " Wood Anatomical Structures of Tropical Acacias and its Implications to Tree Breeding", International Journal of Forestry and Horticulture(IJFH), vol. 3, no. 3, pp 9-16, 2017. http:// dx.doi. org/ 10.20431/2454-9487.0303002

Copyright: (C) 2017 Authors. This is an open-access article distributed under the terms of the Creative Commons Attribution License, which permits unrestricted use, distribution, and reproduction in any medium, provided the original author and source are credited. 